\title{
The Surgical and Cognitive Outcomes of Focal Cortical Dysplasia
}

\author{
Sun Ah Choi, M.D., ${ }^{1,2}$ Ki Joong Kim, M.D., Ph.D. ${ }^{3}$ \\ Department of Pediatrics,' Dankook University Hospital, Cheonan, Korea \\ Department of Pediatrics, ${ }^{2}$ Seoul National University Bundang Hospital, Seongnam, Korea \\ Department of Pediatrics, ${ }^{3}$ Pediatric Clinical Neuroscience Center, Seoul National University Children's Hospital, Seoul National University \\ College of Medicine, Seoul, Korea
}

Focal cortical dysplasia (FCD) is the major cause of intractable focal epilepsy in childhood leading to epilepsy surgery. The overall seizure freedom after surgery ranges between $50-75 \%$ at 2 years after surgery and the long-term seizure freedom remain relatively stable. Seizure outcome after surgery depends on a various factors such as pathologic etiologies, extent of lesion, and types of surgery. Therefore, seizure outcome after surgery for FCD should be analyzed carefully considering cohorts' characteristics. Studies of pediatric epilepsy surgery emphasize the early surgical intervention for a better cognition. Early surgical intervention and cessation of seizure activity are important for children with intractable epilepsy. However, there are limited data on the cognitive outcome after surgery in pediatric $F C D$, requiring further investigation. This paper reviews the seizure and cognitive outcomes of epilepsy surgery for FCD in children. Several prognostic factors influencing seizure outcome after surgery will be discussed in detail.

Key Words : Malformations of cortical development · Pediatrics · Epilepsy · Surgery · Patient outcome assessment.

\section{INTRODUCTION}

Focal cortical dysplasia (FCD) is a subgroup of malformations of cortical development characterized by abnormal cortical lamination, neuronal migration, and differentiation. It was first reported from pathological specimens obtained in ten patients with drug resistant epilepsy ${ }^{50)}$. Over the past decade, several classifications of FCD have been proposed ${ }^{2,39}$. In 2011, the International League Against Epilepsy Task Force proposed a new consensus classification based on histopathological features to yield consistent interobserver and intraob- server reliability ${ }^{5}$.

FCD has a high epileptogenic potential, and is often associated with drug-resistant epilepsy. It is the most common cause of intractable focal epilepsy in children undergoing epilepsy surger $y^{20,32)}$. The primary goal of epilepsy surgery for intractable epilepsy is to achieve seizure freedom and eliminate adverse consequences of continuing antiepileptic drug (AED) treatment. When children achieve seizure freedom after successful epilepsy surgery, withdrawal of AEDs is generally considered. After assessing the benefits of AED discontinuation and the risk of seizure recurrence after withdrawal, clinicians

- Received : January 3, $2019 \bullet$ Revised : January 18, $2019 \bullet$ Accepted : January 26, 2019

- Address for reprints : Ki Joong Kim, M.D.

Department of Pediatrics, Pediatric Clinical Neuroscience Center, Seoul National University Children's Hospital, Seoul National University College of Medicine, 101 Daehak-ro, Jongno-gu, Seoul 03080, Korea

Tel : +82-2-2072-3367, Fax : +82-2-743-3455, E-mail : pednr@snu.ac.kr

This is an Open Access article distributed under the terms of the Creative Commons Attribution Non-Commercial License (http://creativecommons.org/licenses/by-nc/4.0) which permits unrestricted non-commercial use, distribution, and reproduction in any medium, provided the original work is properly cited. 
decide whether and when to stop the AEDs. For young children, additional objective is to optimize neuropsychological development and improve the quality of life after surgery ${ }^{13)}$.

In this article, we focused on the seizure and cognitive outcomes of epilepsy surgery in pediatric FCD series. Moreover, we reviewed the prognostic factors for favorable outcome after epilepsy surgery.

\section{SEIZURE OUTCOME}

Seizure outcomes after epilepsy surgery has been improved over time with the advancement of preoperative diagnostic methods and surgical techniques ${ }^{47,54)}$. The overall seizure-free outcome after surgery ranges from 50 to $75 \%{ }^{7,9,12,29)}$. Details of the selected surgical series are shown in Table 1. Seizure outcomes after surgery are dependent on a number of factors including pathologic etiologies, extent of lesion, and types of surgery. Series that analyzed mostly short term follow-up after surgery presented better seizure outcome ${ }^{35,52}$. These surgical

Table 1. Cohort characteristics and outcomes after epilepsy surgery in children with focal cortical dysplasia/malformation of cortical development

\begin{tabular}{|c|c|c|c|c|c|c|c|}
\hline Study & $\begin{array}{l}\text { No. of } \\
\text { patients }\end{array}$ & $\begin{array}{c}\text { Mean age } \\
\text { at surgery } \\
\text { (years) }\end{array}$ & Pathology & $\begin{array}{l}\text { Lesion on } \\
\text { MRI }\end{array}$ & $\begin{array}{l}\text { Mean } \\
\text { follow-up } \\
\text { period }\end{array}$ & $\begin{array}{c}\text { Engel I } \\
\text { outcome }\end{array}$ & $\begin{array}{l}\text { Predictors of favorable } \\
\text { outcome }\end{array}$ \\
\hline Kloss et al. ${ }^{26)}(2002)$ & $68(P)$ & 5.9 & $\begin{array}{l}\text { FCD I 60\%, FCDII } \\
\text { 40\%; tumors and } \\
\text { dual pathology } \\
\text { excluded }\end{array}$ & $95 \%$ & $\begin{array}{l}2 \text { years or } \\
\text { more }\end{array}$ & $50 \%$ & Complete resection \\
\hline Hudgins et al. ${ }^{23)}$ (2005) & $15(P)$ & 7.8 & $\begin{array}{l}\text { FCD with dual } \\
\text { pathologies }\end{array}$ & $60 \%$ & 4 years & $60 \%$ & $\begin{array}{l}\text { MRI visible lesion, higher } \\
\text { pathologic severity }\end{array}$ \\
\hline Cossu et al.. ${ }^{12)}(2008)$ & $113(P)$ & 8.8 & $\begin{array}{l}\text { FCD/MCD with } \\
\text { tumors and other } \\
\text { pathologies }\end{array}$ & $96 \%$ & 55.1 months & $68 \%$ & $\begin{array}{l}\text { Unifocal lesion on MRI, older age } \\
\text { at seizure, complete resection, } \\
\text { unilobar temporal resection, } \\
\text { glial-neuronal tumors }\end{array}$ \\
\hline Krsek et al. ${ }^{29)}$ (2009) & $\begin{array}{c}149(5 \mathrm{~A} \& \\
144 \mathrm{P})\end{array}$ & NR & $\begin{array}{l}\text { FCD histology tumors } \\
\text { and dual pathology } \\
\text { excluded }\end{array}$ & $\begin{array}{c}71 / 108 \\
(66 \%)\end{array}$ & $\begin{array}{l}6.5 \text { years; } 113 \\
\text { with } 5 \text {-year } \\
55 \text { with } \\
10 \text {-year }\end{array}$ & $55 \%$ & Complete resection \\
\hline Krsek et al. ${ }^{30)}$ (2009) & $40(P)$ & 7.0 & $\begin{array}{l}\text { FCD/MCD with HS; } \\
\text { tumors and dual } \\
\text { pathology excluded }\end{array}$ & $90 \%$ & 4.39 years & $35 \%$ & Complete resection, FCD type II \\
\hline Phi et al.." (2010) & $41(P)$ & 9.0 & FCD histology & $54 \%$ & 73 months & $\begin{array}{l}49 \% \text { at } 1 \text { year; } \\
44 \% \text { at } 2 \text { years }\end{array}$ & $\begin{array}{l}\text { MRI visible lesion, complete } \\
\text { resection }\end{array}$ \\
\hline Teutonico et al. ${ }^{52)}$ (2013) & $120(P)$ & 10.0 & $\begin{array}{l}\text { FCD/MCD with tumor } \\
\text { and cryptogenic } \\
\text { lesions }\end{array}$ & $80 \%$ & $\begin{array}{l}57 \text { months; } \\
98 \text { patients } \\
\text { at least } 2 \\
\text { years }\end{array}$ & $77.5 \%$ & $\begin{array}{l}\text { Age of onset of infantile spasms } \\
\text { (>24 months), hypomotor } \\
\text { seizures, phasic postictal deficit, } \\
\text { FCD typell }\end{array}$ \\
\hline $\begin{array}{l}\text { Mühlebner et al. }{ }^{35)} \\
\text { (2014) }\end{array}$ & $60(P)$ & 8 & FCD/MCD pathology & $100 \%$ & 4.4 years & $\begin{array}{l}78 \% \text { at } 1 \text { year; } \\
72 \% \text { at } 4 \text { years }\end{array}$ & $\begin{array}{l}\text { Temporal location, } \\
\text { hemispherotomies, absence of } \\
\text { interictal spikes on postsurgical } \\
\text { EEG, complete resection }\end{array}$ \\
\hline $\begin{array}{l}\text { Ramírez-Molina et al. }{ }^{42)} \\
\text { (2017) }\end{array}$ & $\begin{array}{c}106 \\
(66 \mathrm{~A} \& 40 \mathrm{P})\end{array}$ & NR & Only FCD typell & $\begin{array}{l}97.5 \%(P) \\
84.8 \%(A)\end{array}$ & $\begin{array}{l}1 \text { year or } \\
\text { more }\end{array}$ & $\begin{array}{l}75 \%(P) \\
71 \%(A)\end{array}$ & NR \\
\hline Choi et al.." (2018) & $58(P)$ & 9.4 & FCD pathology & $82.8 \%$ & 5.1 years & $\begin{array}{l}62 \% \text { at } 1 \text { year; } \\
57 \% \text { at } 2 \text { year }\end{array}$ & $\begin{array}{l}\text { MRI visible lesion, complete } \\
\text { resection }\end{array}$ \\
\hline
\end{tabular}

MRI : magnetic resonance imaging, P : pediatrics, FCD : focal cortical dysplasia, MCD : malformation of cortical development, A : adults, NR : not reported, HS : hippocampal sclerosis, EEG : electroencephalography 
series are associated with a decrease in seizure-freedom with postoperative time ${ }^{28,34}$. Some studies reported that seizure outcome at least 2 years after surgery remained stable as longterm outcome ${ }^{15,19,45}$. Therefore, it can be considered that a 2-year postoperative outcome may reflect the long-term seizure outcome.

Seizure outcomes of the two large pediatric surgical series are further discussed here. One of the largest pediatric series analyzed the outcome of 113 children who underwent surgery between 1996 and 2004 ${ }^{12}$. The mean age at surgery was 8.8 years. Pathologic etiologies include not only FCD, but also dual pathologies such as glio-neuronal tumors or mesial temporal sclerosis. The majority (96\%) had abnormal brain magnetic resonance imaging (MRI). At 55 months after the mean postoperative follow-up, $68 \%$ were categorized as Engel's class I, with $60 \%$ being seizure free (Engel's classes Ia and Ic). They reported that focal lesion on MRI, older age at seizure onset, complete resection, unilobar temporal resection, and a glioneuronal tumor had better surgical outcome.

Another series studied the surgical outcome of 149 patients (144 patients were $<20$ years and five adult patients) with a mild malformation of cortical development (mMCD) or $\mathrm{FCD}^{29)}$. Surgery was performed between 1986 and 2006. Of these 149 patients, 29 patients had mMCD, 58 patients were classified as FCD type I, and 52 patients as FCD types II. At 2 years follow-up, 55\% were classified as Engel's class I. With regard to long-term seizure outcome, 113 patients were followedup for at least 5 years after surgery, and $75 \%$ of them remained stable seizure status after the second postoperative year. This study mainly included children with histologically proven $\mathrm{mMCD} / \mathrm{FCD}$, and demonstrated that complete resection is the most important predictive prognostic factor for surgical outcome.

\section{PROGNOSTIC FACTORS OF FAVORABLE OUT- COME}

Several prognostic factors related to surgical outcome have been proposed. It is crucial to select the best surgical candidates based on predictors of favorable surgical outcome. In a meta-analysis of FCD surgical series, complete resection, severe type of histopathology, detection of MRI lesion, and temporal location of the surgery were found to be important prognostic factors ${ }^{8,44}$. However, the heterogeneity of patient populations, types of surgery, and pathologic etiologies between studies may account for the inconsistency in the proposed prognostic factors across various studies.

Complete resection is widely accepted to be the most important prognostic factor for seizure freedom after surgery ${ }^{9,10,12,15,18,19,25,26,29,35)}$. Complete resection is generally defined as complete removal of the lesion on neuroimaging or the interictal and ictal onset zones on intracranial electrode recording. Patients with complete resection achieved $60-70 \%$ chance of becoming seizure free, while those with incomplete resection only achieved $14-22 \%{ }^{9,26,29}$. Complete resection of the visible lesions (lesional zone) and the epileptogenic zone would increase the likelihood of successful surgical outcomes. It is difficult to assert that resection of the visible lesion is sufficiently includes the epileptogenic zone. Indeed, the epileptogenic zone may be organized as the focal lesional site or as a more complex network extending beyond the lesion ${ }^{36,46}$. To delineate epileptogenic zone, patients with normal MRI or poorly localizing electroencephalography undergo intracranial electrode monitoring, electrocorticography, or stereo-electroencephalography. In addition, a resection of the seizure onset zone, which were determined by high-frequency oscillations or lowvoltage fast activities, resulted in a favorable seizure outcome in pediatric $\mathrm{FCD}^{1,17,31)}$. The leading cause of incomplete resection was the overlap between the epileptogenic zone and the eloquent cortex ${ }^{18,21,30,33)}$. When the epileptogenic zone overlaps with eloquent cortex, multiple subpial transections (MST) can be considered; however, the efficacy of MST in epilepsy surgery has not yet been fully elucidated ${ }^{3)}$.

Both pediatric and adults surgical series demonstrated that severe dysplasia usually yields a more favorable outcomes compared with mild cortical dysplasia ${ }^{23,25,27,4,52,55)}$. In a series of 40 pediatric FCD (24 FCD type I and 16 FCD type II), seizure freedom was achieved in 75\% of FCD type II patients, whereas only $21 \%$ of FCD type I patients ${ }^{30}$. Conversely, some studies failed to identify any significant differences between the seizure outcome and severity of histopathology $y^{15,35,57)}$. Compared with FCD, glio-neuronal tumors are known to have greater favorable outcomes ${ }^{12,14,37,52)}$. Furthermore, glioneuronal tumors associated with FCDs (FCD IIIa) showed excellent outcome compared with FCD type I, which was comparable to solitary tumors ${ }^{11)}$.

Cohort studies evaluating predictors of surgical outcome 
reported better outcomes in patients with demonstrated MRI lesions than in those without relevant MRI abnormalities $^{9,12,23,40)}$. A meta-analysis in various surgical groups of patients showed that patients with lesions on MRI had a 2.5 times higher chance of seizure freedom after surgery (odds ratio, 2.5; 95\% confidence interval, 2.1-3.0; $p<0.001)^{51)}$. The same observation has been reported in patients with $\mathrm{FCD}^{44}$. Constellation of MRI findings is diagnostic for FCD in patients with intractable epilepsy. However, MRI findings can often be subtle and difficult to detect, especially for patients with FCD type I. In a previous study, about $20 \%$ of patients with FCD had normal MRI scans ${ }^{32}$. A structural lesion on MRI is likely to be co-located with the epileptogenic cortex. Furthermore, a discrete lesion on MRI may provide substantial information to localize the epileptogenic zone and serve as a marker of the resection area allowing a more effective resection. However, even in the absence of MRI lesion, it may be worthwhile to consider epilepsy surgery in patients with intractable focal epilepsy. Multimodal integrative presurgical evaluation may lead to a good outcome in patients with intractable focal epilepsy, even without demonstrable lesion on $M R I^{24)}$.

In both pediatric and adult FCD series, the seizure outcome of temporal lobe resection was better than that of extratemporal resection $^{8,12,22,35,44)}$. Better localization of the epileptogenic zone and chances of combined dual pathology, such as hippocampal sclerosis, might contribute to improve seizure outcome in temporal lobe resection. Moreover, in temporal lobe resection, there is no need to consider sparing the eloquent areas.

The need for intracranial monitoring was associated with poor outcome ${ }^{6}$. Generally intracranial monitoring is performed when there is uncertainty in the location and extent of the epileptogenic zone. Therefore, poor localization of the epileptogenic zone could be a reason for intracranial monitoring which ultimately results in poor surgical outcome.

\section{COGNITIVE OUTCOME}

Children with FCD frequently have combined developmental and cognitive dysfunction ${ }^{30,32,49,55)}$. Another important aim of epilepsy surgery in children is to improve the overall cognitive outcome. In a study of infants treated surgically for catastrophic epilepsy, Wyllie observed a marked catch-up development in those with at least 50\% reduction in seizures ${ }^{56}$. In a series of 42 children who underwent temporal resection for intractable epilepsy caused by hippocampal sclerosis or dysembryoplastic neuroepithelial tumors, a statistically significant improvement of the full scale intelligence quotients was observed ${ }^{48}$. However, the improvement of cognitive function is not guaranteed after surgery in all patients. A study evaluating the cognitive outcome after epilepsy surgery in preschool children showed that only a few patients gained cognitive improvement after surgery ${ }^{16}$. They reported that patients who achieved seizure-free, shorter duration of epilepsy, and a low preoperative developmental level showed cognitive improve-

Table 2. Cognitive outcome after epilepsy surgery in children with focal cortical dysplasia/malformation of cortical development

\begin{tabular}{|c|c|c|c|}
\hline Study & No. of patients & Inclusion criteria & Comments \\
\hline Roulet-Perez et al. ${ }^{43)}$ (2010) & $11(P)$ & $\begin{array}{l}\text { Early refractory epilepsy } \\
2 \text { FCD type lla, } 4 \text { FCD type } \| b^{*}\end{array}$ & $\begin{array}{l}\text { Only child with FCD type Ilb showed developmental } \\
\text { improvement. }\end{array}$ \\
\hline Ramantani et al. ${ }^{41)}$ (2013) & $30(P)$ & $\begin{array}{l}\text { Early refractory epilepsy } \\
\text { Age at surgery under } 3 \text { years } \\
24 \text { MCD, } 6 \text { glioneuronal tumor included }\end{array}$ & $\begin{array}{l}\text { Most of patients (93\%) showed stabilized } \\
\text { developmental trajectories rather than catch-up. }\end{array}$ \\
\hline Chen et al. ${ }^{7)}$ (2014) & $30(P)$ & $\begin{array}{l}\text { All FCD (1 FCD type la, } 7 \text { FCD type } 1 b, 7 \text { FCD } \\
\text { type Ila, } 12 \text { FCD type } \| \text { llb, } 3 \text { FCD type } I I)^{\dagger}\end{array}$ & $\begin{array}{l}\text { Early seizure onset without cognitive function } \\
\text { deficit and early surgical intervention showed best } \\
\text { cognitive outcome. }\end{array}$ \\
\hline Ramírez-Molina et al. ${ }^{42)}$ (2017) & $106(66 \mathrm{~A} \& 40 \mathrm{P})$ & Only FCD type $\|^{\dagger}$ & $\begin{array}{l}\text { Both groups showed cognitive improvement after } \\
\text { surgery. Age at surgery (duration of epilepsy) did } \\
\text { not affect cognitive outcome. }\end{array}$ \\
\hline
\end{tabular}

*Pathology based on Palmini classification ${ }^{39)}$ : FCD type lla (dysmorphic neurons without balloon cells), and FCD type Illb (dysmorphic neurons and balloon cells). ${ }^{\dagger}$ Pathology based on the new ILAE classification ${ }^{5)}$ : FCD type la (abnormal radial cortical lamination), FCD type Ib (abnormal tangential cortical lamination), FCD type Ila (dysmorphic neurons without balloon cells), FCD type Illb (dysmorphic neurons and balloon cells), FCD type III (FCD with another principal lesions). P : pediatrics, FCD : focal cortical dysplasia, A : adults, MCD : malformation of cortical development 
ment following surgery. However, to the best of our knowledge, studies evaluating the cognitive outcome after epilepsy surgery for FCD are limited (Table 2). A study of 40 children with FCD type II reported that $37.5 \%$ of children showed an improvement after surger $y^{42}$. However, in other pediatric series, a stabilization of cognitive function, rather than a marked improvement, after successful surgery was demonstrated ${ }^{41,43}$. Therefore, cognitive improvement is not guaranteed in all patients after effective epilepsy surgery. Nonetheless, cognitive improvement, at least stabilized cognitive function, is possible after surgery.

The fact that early onset and long duration of epilepsy may be followed by cognitive deterioration suggests a window of vulnerability for irreversible decline of cognition ${ }^{4,38,53)}$. Some pediatric FCD series demonstrated the better cognitive outcomes after surgery in patients with shorter epilepsy duration $^{7,411}$. In contrast, other study opposed that epilepsy duration did not appear to influence cognitive outcome after surger $y^{42}$. Nevertheless, to minimize the detrimental effects of uncontrolled seizure, early surgical intervention and cessation of seizure activity are important for children with intractable epilepsy.

\section{CONCLUSION}

Focal cortical dysplasia is a major cause of focal intractable epilepsy and epilepsy surgery in childhood. The efficacy of epilepsy surgery is dependent on the ability to precisely localize and resect the epileptogenic zone. Among the several prognostic factors, complete resection of the epileptogenic zone is the most powerful predictor for favorable seizure outcome. We observed cognitive improvement or stabilization after surgery in children with FCD. However, more studies to support early surgical intervention for a better cognitive outcome will be required.

\section{CONFLICTS OF INTEREST}

No potential conflict of interest relevant to this article was reported.

\section{INFORMED CONSENT}

This type of study does not require informed consent.

\section{References}

1. Aubert S, Wendling F, Regis J, McGonigal A, Figarella-Branger D, Peragut JC, et al. : Local and remote epileptogenicity in focal cortical dysplasias and neurodevelopmental tumours. Brain 132(Pt 11) : 3072-3086, 2009

2. Barkovich AJ, Kuzniecky RI, Dobyns WB, Jackson GD, Becker LE, Evrard $P$ : A classification scheme for malformations of cortical development. Neuropediatrics $27:$ 59-63, 1996

3. Benifla M, Otsubo H, Ochi A, Snead OC 3rd, Rutka JT : Multiple subpial transections in pediatric epilepsy: indications and outcomes. Childs Nerv Syst 22 : 992-998, 2006

4. Bjørnaes $H$, Stabell $K$, Henriksen 0 , Løyning $Y$ : The effects of refractory epilepsy on intellectual functioning in children and adults. A longitudinal study. Seizure $10: 250-259,2001$

5. Blümcke I, Thom M, Aronica E, Armstrong DD, Vinters HV, Palmini A, et al. : The clinicopathologic spectrum of focal cortical dysplasias: a consensus classification proposed by an ad hoc task force of the ILAE diagnostic methods commission. Epilepsia 52 : 158-174, 2011

6. Bulacio JC, Jehi L, Wong C, Gonzalez-Martinez J, Kotagal P, Nair D, et al. : Long-term seizure outcome after resective surgery in patients evaluated with intracranial electrodes. Epilepsia 53 : 1722-1730, 2012

7. Chen HH, Chen C, Hung SC, Liang SY, Lin SC, Hsu TR, et al. : Cognitive and epilepsy outcomes after epilepsy surgery caused by focal cortical dysplasia in children: early intervention maybe better. Childs Nerv Syst 30 : 1885-1895, 2014

8. Chern JJ, Patel AJ, Jea A, Curry DJ, Comair YG : Surgical outcome for focal cortical dysplasia: an analysis of recent surgical series. J Neurosurg Pediatr 6 : 452-458, 2010

9. Choi SA, Kim SY, Kim H, Kim WJ, Kim H, Hwang H, et al. : Surgical outcome and predictive factors of epilepsy surgery in pediatric isolated focal cortical dysplasia. Epilepsy Res 139 : 54-59, 2018

10. Cohen-Gadol AA, Ozduman K, Bronen RA, Kim JH, Spencer DD : Longterm outcome after epilepsy surgery for focal cortical dysplasia. J Neurosurg $101: 55-65,2004$

11. Cossu M, Fuschillo D, Bramerio M, Galli C, Gozzo F, Pelliccia V, et al. : Epilepsy surgery of focal cortical dysplasia-associated tumors. Epilepsia 54 Suppl 9 : 115-122, 2013

12. Cossu M, Lo Russo G, Francione S, Mai R, Nobili L, Sartori I, et al. : Epilepsy surgery in children: results and predictors of outcome on seizures. Epilepsia 49 : 65-72, 2008

13. Cross JH, Jayakar P, Nordli D, Delalande O, Duchowny M, Wieser HG, et al. : Proposed criteria for referral and evaluation of children for epilepsy surgery: recommendations of the subcommission for pediatric epilepsy surgery. Epilepsia 47 : 952-959, 2006 
14. Englot DJ, Breshears JD, Sun PP, Chang EF, Auguste KI : Seizure outcomes after resective surgery for extra-temporal lobe epilepsy in pediatric patients. J Neurosurg Pediatr 12 : 126-133, 2013

15. Fauser $S$, Essang $C$, Altenmüller DM, Staack AM, Steinhoff BJ, Strobl K, et al. : Long-term seizure outcome in 211 patients with focal cortical dysplasia. Epilepsia $56:$ 66-76, 2015

16. Freitag $H$, Tuxhorn I: Cognitive function in preschool children after epilepsy surgery: rationale for early intervention. Epilepsia 46 : 561-567, 2005

17. Fujiwara $H$, Greiner HM, Lee KH, Holland-Bouley KD, Seo JH, Arthur $T$, et al. : Resection of ictal high-frequency oscillations leads to favorable surgical outcome in pediatric epilepsy. Epilepsia 53 : 1607-1617, 2012

18. Hader WJ, Mackay M, Otsubo H, Chitoku S, Weiss S, Becker L, et al. : Cortical dysplastic lesions in children with intractable epilepsy: role of complete resection. J Neurosurg 100(2 Suppl Pediatrics) : 110-117, 2004

19. Hamiwka L, Jayakar P, Resnick T, Morrison G, Ragheb J, Dean P, et al. : Surgery for epilepsy due to cortical malformations: ten-year follow-up. Epilepsia 46 : 556-560, 2005

20. Harvey AS, Cross JH, Shinnar S, Mathern GW, ILAE Pediatric Epilepsy Surgery Survey Taskforce : Defining the spectrum of international practice in pediatric epilepsy surgery patients. Epilepsia 49 : 146-155, 2008

21. Hauptman JS, Mathern GW : Surgical treatment of epilepsy associated with cortical dysplasia: 2012 update. Epilepsia 53 Suppl 4 : 98-104, 2012

22. Hirfanoglu T, Serdaroglu A, Kurt G, Erdem A, Capraz I, Bilir E, et al. : Outcomes of resective surgery in children and adolescents with focal lesional epilepsy: the experience of a tertiary epilepsy center. Epilepsy Behav 63 : 67-72, 2016

23. Hudgins RJ, Flamini JR, Palasis S, Cheng R, Burns TG, Gilreath CL : Surgical treatment of epilepsy in children caused by focal cortical dysplasia.

Pediatr Neurosurg 41 : 70-76, 2005

24. Jayakar P, Dunoyer C, Dean P, Ragheb J, Resnick T, Morrison G, et al. : Epilepsy surgery in patients with normal or nonfocal MRI scans: Integrative strategies offer long-term seizure relief. Epilepsia 49 : 758-764, 2008

25. Kim DW, Lee SK, Chu K, Park KI, Lee SY, Lee CH, et al. : Predictors of surgical outcome and pathologic considerations in focal cortical dysplasia. Neurology 72 : 211-216, 2009

26. Kloss S, Pieper T, Pannek H, Holthausen H, Tuxhorn I : Epilepsy surgery in children with focal cortical dysplasia (FCD): results of long-term seizure outcome. Neuropediatrics 33 : 21-26, 2002

27. Kral $T$, Clusmann $H$, Blümcke I, Fimmers $R$, Ostertun $B$, Kurthen $M$, et al. : Outcome of epilepsy surgery in focal cortical dysplasia. J Neurol Neurosurg Psychiatry 74 : 183-188, 2003

28. Kral $T$, von Lehe $M$, Podlogar $M$, Clusmann $H$, Süssmann $P$, Kurthen $M$, et al. : Focal cortical dysplasia: long term seizure outcome after surgical treatment. J Neurol Neurosurg Psychiatry 78 : 853-856, 2007

29. Krsek P, Maton B, Jayakar P, Dean P, Korman B, Rey G, et al. : Incomplete resection of focal cortical dysplasia is the main predictor of poor postsurgical outcome. Neurology 72 : 217-223, 2009

30. Krsek P, Pieper T, Karlmeier A, Hildebrandt M, Kolodziejczyk D, Winkler $P$, et al. : Different presurgical characteristics and seizure outcomes in children with focal cortical dysplasia type I or II. Epilepsia 50 : 125137, 2009

31. Lagarde S, Bonini F, McGonigal A, Chauvel P, Gavaret M, Scavarda D, et al. : Seizure-onset patterns in focal cortical dysplasia and neurodevelopmental tumors: relationship with surgical prognosis and neuropathologic subtypes. Epilepsia 57 : 1426-1435, 2016

32. Lerner JT, Salamon N, Hauptman JS, Velasco TR, Hemb M, Wu JY, et al. : Assessment and surgical outcomes for mild type I and severe type II cortical dysplasia: a critical review and the UCLA experience. Epilepsia 50 : 1310-1335, 2009

33. Marusic P, Najm IM, Ying Z, Prayson R, Rona S, Nair D, et al. : Focal cortical dysplasias in eloquent cortex: functional characteristics and correlation with MRI and histopathologic changes. Epilepsia 43 : 27-32, 2002

34. Mathern GW, Giza CC, Yudovin S, Vinters HV, Peacock WJ, Shewmon DA, et al. : Postoperative seizure control and antiepileptic drug use in pediatric epilepsy surgery patients: the UCLA experience, 1986-1997. Epilepsia 40 : 1740-1749, 1999

35. Mühlebner A, Gröppel G, Dressler A, Reiter-Fink E, Kasprian G, Prayer D, et al. : Epilepsy surgery in children and adolescents with malformations of cortical development--outcome and impact of the new ILAE classification on focal cortical dysplasia. Epilepsy Res 108 : 1652-1661, 2014

36. Munari T, Berta E, Francione S, Tassi L, Lo Russo G, Mai R, et al. : Clinical ictal symptomatology and anatomical lesions: their relationships in severe partial epilepsy. Epilepsia 41 Suppl 5 : S18-S36, 2000

37. Nagarajan L, Lee M, Palumbo L, Lee S, Shah S, Walsh P, et al. : Seizure outcomes in children with epilepsy after resective brain surgery. Eur J Paediatr Neurol 19 : 577-583, 2015

38. Neyens LG, Aldenkamp AP, Meinardi HM : Prospective follow-up of intellectual development in children with a recent onset of epilepsy. Epilepsy Res 34 : 85-90, 1999

39. Palmini A, Najm I, Avanzini G, Babb T, Guerrini R, Foldvary-Schaefer N, et al. : Terminology and classification of the cortical dysplasias. Neurology 62(6 Suppl 3) : S2-S8, 2004

40. Phi JH, Cho BK, Wang KC, Lee JY, Hwang YS, Kim KJ, et al. : Longitudinal analyses of the surgical outcomes of pediatric epilepsy patients with focal cortical dysplasia. J Neurosurg Pediatr 6 : 49-56, 2010

41. Ramantani G, Kadish NE, Strobl K, Brandt A, Stathi A, Mayer H, et al. : Seizure and cognitive outcomes of epilepsy surgery in infancy and early childhood. Eur J Paediatr Neurol 17 : 498-506, 2013

42. Ramírez-Molina JL, Di Giacomo R, Mariani V, Deleo F, Cardinale F, Uscátegui-Daccarett AM, et al. : Surgical outcomes in two different age groups with focal cortical dysplasia type II: any real difference? Epilepsy Behav 70(Pt A) : 45-49, 2017

43. Roulet-Perez E, Davidoff V, Mayor-Dubois C, Maeder-Ingvar M, Seeck M, Ruffieux $C$, et al. : Impact of severe epilepsy on development: recovery potential after successful early epilepsy surgery. Epilepsia 51 : 12661276,2010 
44. Rowland NC, Englot DJ, Cage TA, Sughrue ME, Barbaro NM, Chang EF, et al. : A meta-analysis of predictors of seizure freedom in the surgical management of focal cortical dysplasia. J Neurosurg 116 : 1035-1041, 2012

45. Salanova V, Markand O, Worth R : Longitudinal follow-up in 145 patients with medically refractory temporal lobe epilepsy treated surgically between 1984 and 1995. Epilepsia 40 : 1417-1423, 1999

46. Sevy A, Gavaret M, Trebuchon A, Vaugier L, Wendling F, Carron R, et al. : Beyond the lesion: the epileptogenic networks around cavernous angiomas. Epilepsy Res 108 : 701-708, 2014

47. Sisodiya SM : Surgery for malformations of cortical development causing epilepsy. Brain 123 (Pt 6) : 1075-1091, 2000

48. Skirrow C, Cross JH, Cormack F, Harkness W, Vargha-Khadem F, Baldeweg $T$ : Long-term intellectual outcome after temporal lobe surgery in childhood. Neurology 76 : 1330-1337, 2011.

49. Tassi L, Colombo N, Garbelli R, Francione S, Lo Russo G, Mai R, et al. : Focal cortical dysplasia: neuropathological subtypes, EEG, neuroimaging and surgical outcome. Brain 125(Pt 8) : 1719-1732, 2002

50. Taylor DC, Falconer MA, Bruton CJ, Corsellis JA : Focal dysplasia of the cerebral cortex in epilepsy. J Neurol Neurosurg Psychiatry 34 :
369-387, 1971

51. Téllez-Zenteno JF, Hernández Ronquillo L, Moien-Afshari F, Wiebe $S$ : Surgical outcomes in lesional and non-lesional epilepsy: a systematic review and meta-analysis. Epilepsy Res 89 : 310-318, 2010

52. Teutonico F, Mai $R$, Veggiotti $P$, Francione $S$, Tassi $L$, Borrelli $P$, et al. : Epilepsy surgery in children: evaluation of seizure outcome and predictive elements. Epilepsia 54 Suppl 7 : 70-76, 2013

53. Vingerhoets $G$ : Cognitive effects of seizures. Seizure $15: 221-226$, 2006

54. West $S$, Nolan SJ, Newton R : Surgery for epilepsy: a systematic review of current evidence. Epileptic Disord 18 : 113-121, 2016

55. Widdess-Walsh $P$, Kellinghaus $C$, Jeha L, Kotagal $P$, Prayson R, Bingaman $W$, et al. : Electro-clinical and imaging characteristics of focal cortical dysplasia: correlation with pathological subtypes. Epilepsy Res 67 : 25-33, 2005

56. Wyllie E : Surgery for catastrophic localization-related epilepsy in infants. Epilepsia 37 Suppl 1 : S22-S25, 1996

57. Xue H, Cai L, Dong S, Li Y : Clinical characteristics and post-surgical outcomes of focal cortical dysplasia subtypes. J Clin Neurosci 23 : 68-72, 2016 